\title{
CONCEPTION OF ARTISTIC WORD AS ONTOLOGICAL MEANINGFULNESS IN MODERN LITERARY STUDY
}

\section{Sventsitskaya E. M.}

\section{INTRODUCTION}

Development of modern theory of literature is predefined by the new stage in realization of multipolarism of this science, and also intensifying of tension between the poles. It is about objectively-logical well-proven and subjectively-vivid imagine, reserved structure of text and endlessness of interpretation context, aesthetic meaningfulness of work and its' semantic depth. In these breaks, co-operating of literary study is represented with literature - the art of word. All of it results in widening of limits of this science and loss by its object. Therefore modern literary criticism aims to comprehend again the specific of literature on a ground of other types of art, and also other forms of speech. One of methods of such comprehension is a specification of concept of artistic word that is often used, but it is certain not enough.

The aim of this work is to consider and systematize theoretic and literature concepts that are based on claim of ontological nature of the artistic word.

\section{Artistic word as aesthetic reality (G.O. Vinokur, D.K. Rensom)}

The source of this conception is first of all O.O. Potebnia. In his work "Aesthetics and poetics" he writes: "Word is a substance, and it is illustrated not only by philological connection of words that mean a "word" and "substance", but also by the common for all words belief that they define the essence of a phenomena. Word, as essence of substance, in prayer or in spell, retains power over nature. Mysterious connection of word and object is not limited to one sacred words of spells: it remains in words and in everyday speech"1. This stream of ideas influenced the Russian religious philosophy, and first of all P.O. Florensky: "Word is a reality expressed by the word, not its' duplication, not a copy placed by its' side; but the very reality in its' numerological being”"2. In further

\footnotetext{
${ }^{1}$ Потебня А.А. Эстетика и поэтика. Москва: Искусство, 1976. С. 173.

2 Флоренский П.А. Имеславие как философская предпосылка // Флоренский П.А. У водоразделов мысли. Москва: Правда, 1990. Т. 2. С. 293/
} 
development of a study of literature we find an ontological tendency of dual character: from one side, a word is a display of existence as a philosophical category, and, on the other hand, it is a separate existence that cannot be shortened to any other. This split is clearly seen in comparison of works of O.F. Losev and G.O. Vinokur.

In works of O.F. Losev the word is conceptualized as ontological meaningfulness, it contains an object: the "A living word contains an intimate relationship to the object and deep knowledge of its' cherished depths. Name of an object is not simply our noema, and not simply an object. The name of an object is an arena of meeting of who perceives and the perceived, more precisely, of who tries to know and what is to be known. The name contains an intimate unity of the disconnected spheres of existence, unity that results in indivisible existence, not any more simply "subjective" or simply "objective" consciousness. The name of an object is a whole organism of its' life and other life"3. Let's notice that the concept of O.F. Losev is characterized by the fact that the existence of a word is engrained in the subject. O.O. Potebnia clearly states that the "force of a word is not by any means a consequence of the moral force of the speaker"4. In addition, both O.O. Potebnia and P.O Florensky postulate the influence of word upon reality. It is that magic word that Russian religious philosophy talks about. In views of O.F. Losev a word not as much influences, it rather connects, it becomes a "venue", as we see. Actually, a word here appears as a mediator between the subject and the existence, between life and existence; a mediator that contains all characteristics of the combined phenomena.

The ideas of O.O. Potebnia were reconsidered by G.O. Vinokur in a different, materially-linguistic aspect. In his work "About the study of language of literary works" he departs from a formalist statement that a national language is the material of art of word: "a poetic language can also mean the language in it's artistic function, language as material of art, unlike, for example, language as material of logical idea or science. But the language of a poetic work in itself is a certain artistic work" 5 . Him a thesis belongs to, that "language and there is an in itself poetry" 6 . Also him a statement belongs to, that a "poetic language is that usually name a vivid language", . These ideas, certainly, call with

\footnotetext{
${ }^{3}$ Лосев А.Ф. Философия имени. Москва: Издательство МГУ, 1990. С. 38-39.

${ }^{4}$ Потебня А.А. Эстетика и поэтика. Москва: Искусство, 1976. С. 173/

${ }^{5}$ Винокур Г.О. О языке художественной литературы. Москва: Высшая школа, 1991. С. 51.

${ }^{6}$ Там само. С. 27.

${ }^{7}$ Там само. С. 27.
} 
conception of O. Potebnia. But G.O. Vinokur places accents little different: “...that special function of language, that we name poetic, would follow to explain by analogy with other types of art" ${ }^{\text {" }}$. It goes out from here, that a poetic word is "special modus of language reality", her aesthetic existence.

A researcher specifies, that a national language differs from the language of poetry an arbitrary betweenness by a word and his value: "In a common language as instruments of practical consciousness of copulas between a word and mark by this word object are fully arbitrary and presents by a soba result of difficult chain of historical chances. There is not sense to ask yourself, дa it practically and does not occur, while we do not call to the questions of history of language, why fish for us is named a word "fish" ". An internal form that creates explained of sense of word a context appears in work, by authorial intention: "And if before us really work of art, then a question about that, why corresponding more common maintenance is passed in this case by a word "fish", becomes an already not idle question. In fact, in another cases he would be adopted by quite another word. But will name in the fairy-tale of Pushkin this common maintenance by a not word "fish", but some other, and this work of art, in every case, will be destroyed"11.

In logic of G.O. Vinokur, a language becomes work of art exactly then, when correlated inter-word and by the words motivated by authorial intention in their a-motivational value. It takes place then, when "language with all by the direct values in a poetic word usage as though all kicked about in a theme and idea of artistic intention"12. A word is in G.O. Vinokur, thus, is the name, character, special world artistic intention will be realized in that.

Especially clearly it is visible in work of G.O. Vinokur of "Maiakovsky is an innovator of language". Model and interest in futurism, in fact for futurists, as writes G.O. Vinokur in this work, a word rids of connection with the article of idea. It is the again created name of object ${ }^{13}$. In a preface to this work of G.O. Vinokur talks about such feature of poetic language, as possibility of creation of occasional words. It is words potentially possible. They are created by a poet in accordance with his authorial task. Here aesthetic transformation takes place within

\footnotetext{
${ }^{8}$ Винокур Г.О. О языке художественной литературы. Москва: Высшая школа, 1991. С. 28.

${ }^{9}$ Там само. С. 62.

10 Там само. С. 52.

11 Там само. С. 52.

12 Там само. С. 53.

13 там само. С. 329.
} 
the framework of word. V.P. Grigoriev in the preface to the book of G.O. Vinokur not by chance talks that a word for him - the "sign of art". He means, obviously, that it specifies on the special nature of reality, created them.

In foreign literary criticism of 30-40th also going analyzed near a poetic word as to ontological meaningfulness. Here also there are two interpretations of this ontological meaningfulness: from one side, consideration of poetic word as the special sort of existence with the structure and mutual relations between her elements, and, on the other hand, consideration of poetic word as to the display of existence of the world.

The first tendency clearly showed up in a robot D. Rensom "New criticism". D. Rensom goes out that a poetry deals with the special world - world of essences, unlike the world of the phenomena, and in force of it becomes separate existence: "I consider that excellent signs of poetry are ontological. A poetry deals with those forms of existence, level of objectivity, that does not yield to scientific interpretation. The world in that we live is different from the next world or, rather, the next numerous worlds that is investigated by science. These worlds are the impoverished, simplified copies of the real world just castrated. A poetry has for an object again to open for us this "denser", essence world about that we due to the remembrances have certain presentation. Poetry, thus, there is a form of cognition fundamentally, or ontological”"14.

The special existence of poetic word of D. Rensom binds to cooperation of rhythm and maintenance, their mutual necessity (“...a construction is verses on ambivalent basis: the sought after value and sought after size - appears... by a difficult task" ${ }^{15}$ ). Unifying cooperation of rhythm and maintenance becomes possible because both they have some zone of vagueness. And rhythm, and maintenance in becoming assume a rejection and variations. The same opinion can be expressed in number of different ways. A size, in this logic, appears overcoming of static set of meter and embodiment of becoming of individual idea: "Idea, that assumes variations that do her more suitable for a poetic size, cannot be initially certain. To save an idea in a that kind in that she is determined by own laws, it is impossible, if we gather to build on her to the poetic size. And on the other hand, a rhythmic form must be partly indefinite, if she applies on that, to incarnate any idea.

\footnotetext{
14 Рэнсом Д.К. «Новая критика» // Зарубежная эстетика и теория литературы XIX - XX веков. Москва: Издательство МГУ, 1987. С. 178.

15 Там само. С. $180 /$
} 
There is no sense to try to define a rhythm in good time, because an idea will correct it" ${ }^{\prime 16}$.

Thus, an and rhythm, and maintenance, exist as set, to poetic work. And the process of this becoming shows their mutual correction. Hereupon D. Renson distinguishes initial maintenance and additional maintenance (what arises up as a result of co-operating with a rhythm), and also initial sounding and additional sounding (what arises up as a result of co-operating with maintenance). He determines initial, given as a structure, and the individual is created - as an invoice of poetic work.

Is there a question: as in the already created poetic word to delimit a structure and invoice? Initial maintenance yet can in somehow separate, erecting poetic expression to logical. Separating of the initial sounding appears yet more problematic. In fact exactly this D. Renson will postulate as a basic task of "new criticism": "I come to the next conclusion: differentiation of these elements, and especially - initial sense and additional sense and is the task of criticism of par excellence” ${ }^{\not 17}$. However at the concrete analysis of works (especially verse of W. Wordthword) the unclearness of such differentiation clears up: "We see that euphony was violated not only, but something took place and with logic of idea : it became clear that "with rays and flowers" needed a row just in an order to complete a couplet. But also, the following by him couplet also is not enough economy of the logics of thought. Words of structure of majestic frame (building of majestic forms) - it not that other, as majestic structure (majestic building), and the word of frame is simply added for a rhyme" 18 . In the brought expression over especially notedly, that interpretation of becoming of additional maintenance in co-operating with a rhythm together with final establishment, that a "size squeezes a rhythm"19, in principle, fully subjective and abut against psychology. That one critic it seems to a logical unconsent, other can be perceived as a change of normative word usage that carries in itself the necessary increase of maintenance. In addition, the estimation of appropriateness of that or other word looks problematic in the already prepared work from the point of view of "logic of idea”. It goes out that the prepared idea is separately from work, and work is examined from the point of view of accordance to her.

\footnotetext{
${ }^{16}$ Рэнсом Д.К. «Новая критика» // Зарубежная эстетика и теория литературы XIX - XX веков. Москва: Издательство МГУ, 1987. С. 180.

${ }^{17}$ Там само. С. 182.

18 там само. C. 185.

19 Tva camo. C. 185.
} 
Will pay attention thus, that additional maintenance was before determined as above logical. The look of $\mathrm{D}$. Renson to the special existence of poetic word can be described as objective, such that dismembers : "...a verse is an object that contains not two, but four elements: not about one hundred certain sense, but initial sense, substantial part of value, that folds logical structure, and additional sense, initial that part of value, that does not belong to the logical structure. Except it have not only initial sounding is an initial size but also additional sound" ${ }^{20}$.

Thus, the work is some prepared structure that combines in itself elements from out-of-text reality and text: "Stowage of poetic work is an operation at that an authorial idea aims to press a size, and size - idea" ${ }^{21}$ ). But, on the other hand, a psychological tendency resists this structural, operating approach in the estimation of semantic changes. Its structural duality of the expression- sounding and maintenance plan and created designed directly on space of existence, in that this expression is opened out: "Melodies however there is two, although they sound simultaneously, and a poetic phrase is an only act. Ontological he means the reunions of two different worlds - essence and almost elusive - and construction of expression in other measuring" 22 .

Thus, according to D. Renson near a poetic word is marked a break between the rational clearness of structure that characterizes his existence, and psychological ambiguousness and diffusion of functioning of this structure.

\section{An artistic word as display of existence in its' integrity (M. Highdegger, M. Gey)}

The second tendency is going near a word as to the display of existence in his integrity - it arises up in works of M. Highdegger. Actual study of literature problems M. Highdegger certainly, did not put, his attitude toward a poetic word swam out from his interpretation of art in general.

An art, how is it visible from work "Source of artistic creation", M. Highdegger presents as a display pure: "That takes place here? Is What created in creation? The pure enters in opennes of the existence. Openness of existence Greeks named the word of aleteya” ${ }^{23}$. At the same

\footnotetext{
${ }^{20}$ Рэнсом Д.К. «Новая критика» // Зарубежная эстетика и теория литературы XIX - XX веков. Москва: Издательство МГУ, 1987. С. 182.

${ }^{21}$ Там само. С. 178.

${ }^{22}$ Там само. С. 193.

23 Хайдеггер М. Исток художественного творения // Зарубежная эстетика и теория литературы XIX - XX веков. Москва: Издательство МГУ, 1987. С. 278.
} 
time it is a display of truth pure: "In creation, if in him there is opening, dissolution of truth pure for existence of him such and such, performing of truth" is created"; "Artistic creation opens up the inherent to him method of existence pure. In creation is ending this opening is an exposure, thus truth pure. In artistic creation truth lays pure itself in creation. Truth is such laying-on of truth in creation" ${ }^{24}$. Already here we see fundamental coupled concepts "existence" and "truth". Truth opening of existence pure, existence - opening of presence of truth. These two concepts, thus, cross in a category pure.

Characteristically, that these concepts in M. Highdegger cross not only, but practically identical. In a number of works ("Existence and time”, "Law of equality" and other). M. Highdegger determines existence as presence : "Existence due to that all pure crystal-clear as just the same pure, this existence means a presence. In the relation of imagined present person a presence presents itself as permission to be present”. Speech goes, thus, about the phenomenological understanding of existence as such, that opens, expressed and thought.

By what character does existence open? In the work "Source of artistic creation" about it is talked so: "In the middle of pure an open place exists on the whole. It is a road clearance. If to think him coming from pure, then he is being all pure. Therefore, a not middle that does not know is surrounded pure, and, on the contrary, middle that clarifies, the all pure surrounds, twirling around pure, as Nothing, that we do not almost know. Pure only then can be pure, when it enters and comes forward in clarified of road clearance. Only a road clearance gives to us, to the people, and access to pure - to pure, that not the same, that we, and to pure that is we. Due to a road clearance pure in certain, besides different degree there is not hidden. And hidden the pure can be only in spaces clarified. A road clearance the pure enters into that is at the same time and close" ${ }^{25}$.

Thus, existence pure shows a soba the dynamics of brightening and concealment. Here a concealment can be intelligent only on condition of brightening. In this situation of "enlightening", thus illumination pure in his existence, is founding of possibility to think pure as present and concrete existence-presence (“zein”).

It is needed to mark that founding for such erection is a category pure: "...creation as such exists only in what truth is created into, and

\footnotetext{
${ }^{24}$ Хайдеггер М. Исток художественного творения // Зарубежная эстетика и теория литературы XIX - XX веков. Москва: Издательство МГУ, 1987. С. 281.

${ }^{25}$ Там само. С. 291.
} 
truth exists only so far as, as builds itself inward something pure” 26 . And truth, and existence, is present in a presence not abstractly. They are real so far as, as exist in pure. And it is fundamentally important here, that pure not only present in a presence, is but also somehow illuminated. Highdegger's "brightening” synonymous to opening and, in principle, correlated with perception. Actually, possibility of perception and brings in a dynamic at existence pure. By the concentrated expression of this dynamics that clarifies, and there is an art: "And the hidden existence is then clarified. Such light builds lighting up inward of creation. Lighting up, built-in inward creation, is wonderful. Beauty is method truth exists that, - non-hidden" 27 .

Another part of equations lines up on this basis. An art equates with a poetry (or a poetry dissolves in an art): "Truth, being brightening or closing pure, being made poetically. All art - such that gives to be to truth pure as such, - after the essence there is a poetry". A poetry is equated with an idea: “...any comprehending idea is poetry, and any poetry is an idea. Both belong each other in turning to that conversation in that the unsaid said already, because he is idea as unity"28.

That, actually, does stand after all these equations? Question that more actual, that one of late works of M. Highdegger is named "Law of equality". The equality based on interconnection of the heterogeneous phenomena is a law of mythological world view. Undoubtedly, mythology is here well-proven to the limit, and as a result already it arises up new quality is certain. Equality in M. Highdegger only on the face of it is beating back in multiplicity something only.

In fact a base structure of mutual relations of existence and truth, truth and poetry is "arranging", being inwardly and "laying-on" inward, and at the same time being of point of crossing in pure. In principle, all these сутності is included in each other, as parts of matrix. Exactly this including creates possibility of equating. Thus, here is such complication, that already converts mythological attitude into the way of thinking, abstracting. In this sense very characteristically, that, pushing off from traditional metaphysics, M. Highdegger, essentially, creates the metaphysics based on a removal of hyerarchy and hypostazation of existence.

The pure is basis of connection of language and poetry: "Language first gives the name pure, and due to this name the pure gets a word and

${ }^{26}$ Хайдеггер М. Исток художественного творения // Зарубежная эстетика и теория литературы XIX - XX веков. Москва: Издательство МГУ, 1987. С. 303.

${ }^{27}$ Там само. С. 293.

${ }^{28}$ Хайдеггер М. Время и бытие. Москва: Республика, 1993. С. 273. 
phenomenon first. Such name, definition pure, first pre-destination him for existence. Such name is throwing of light complains in that, exactly enters pure in spaces exposed. A poetry is word of opening pure. And accordingly, every language is performing of such speech"29. As see, and in a language, and there is the same process of concealment and opening pure in a poetry, that and in existence, and in truth, and in an art in general (at once there is the same theme of road clearance - "light"). For this reason, a "language is poetry in substantial sense", and, thus, word the poetic in substantial sense is a word is a language.

In-process "word" especially clearly shows up mythological character of thinking of philosopher. He concentrates the attention round the problem of the name, on that the word-name, that V. Ivanov attributed languages" to the "mythological epoch, and in his description too there is a row of general moments. First of all, it a word is not simply related to the thing, but identical to it: "Where a word is not enough, there is not a thing. Only a word that is in an order allots a thing with existence" 30 . The same as representatives of Russian religious philosophy, M. Highdegger talks about power of word, however in the coordinates of own metaphysics: "Word shows the ancient, higher power suddenly. It already is not simple grip of the name on the already presented presence, not simply instruments for the image of existent given. Opposite, self-word to the giver presence, thus existence in that something appears as existing"31; "Power of word catches fire as persuasion of existence of thing. A word begins to shine as that collection that first enters a present person in his presence" 32 .

However these postulates take place from a bit other logic. V. Ivanov will nurse from a "mythological epoch languages", and this being for him clearly reflected. M. Highdegger will nurse languages from mifologization. It becomes for him so universal in sense of penetration in contiguous categories and reflections in them, as well as existence pure.

Actually, language and there is a method of existence pure, all his dynamics of opening-concealment holds out in that: "Language in the essence is expression of organism, there is she and by expression of living creature. Therefore her never and it is not succeeded to comprehend neither from her sign, nor even from her semantics. A language is the

${ }^{29}$ Хайдеггер М. Исток художественного творения // Зарубежная эстетика и теория литературы XIX - XX веков. Москва: Издательство МГУ, 1987. С. 306.

${ }^{30}$ Хайдеггер М. Время и бытие. Москва: Республика, 1993. С. 303.

${ }^{31}$ там само. С. 306.

32 там само. С. 312. 
illuminative-hiding phenomenon of existence"33. For this reason, a "language is a house of existence", that she contains all his lines inwardly and shows them through itself. A language creates possibility of their opening, an opening method is a word. Therefore, self-existence generates a word: "Existence, enlightening, asks words, in always talks for itself. Giving about itself to know, it in turn allows to the reflect idea, that exists, that gives one's word to him. Word that itself comes forward in the road clearance of existence. Only thus a language first begins to be devoted, and, however, by a ruling by us method"34. Thus, speech goes exactly about power of language, a "language talks". More precisely, pure, that opens through her, talks about itself and with itself. For this reason, a language is determined $\mathrm{M}$. Highdegger as a monologue. Power of language exactly shows up in that she, setting the name of thing, the substance of the name determines.

Therefore, a word does not specify on certain maintenance, but shows him through itself: to "Speak from each other means: together to pronounce on something, show to each other such that discovers in what speech goes about, discussed, to destroy his by on light. It is Unsaid of not only that does not yield to announcement, but indescribable, yet not shown, that did not yet attain reality" ${ }^{35}$.

Exactly this brightening of pure, leading out of him in the state of exposure and presents by a soba that "action", that M. Highdegger puts "stories" (to "hydrophobia") in basis - clarifying indication: the "Propulsive to pointing of story is personality. It brings a present person over and absent each time to his own, from where the last shows itself in itself and the method is. It defines that comes true, what a story collapses just in her pointing, will name an event. It is creating free space of road clearance, where a present person can enter for a stay, where the absent can go from, keeping the stay in this departure. That comes true by an event through a story - is neither operating of some reason nor investigation under some founding. Personification, that gives to come true, event more substantial, than any action, performing and ground. Existence by gives an event, and nothing else" 36 . Very characteristically, that "inpersonality" - in the original of "eignen" - consonant "Ereignis" are events. This word has connotations - "lighting" up. Yes, from one side, a word dissolves in the event of existence. But on the other hand, the

\footnotetext{
${ }^{33}$ Хайдеггер М. Время и бытие. Москва: Республика, 1993. С. 199.

${ }^{34}$ Там само.. С. 219.

${ }^{35}$ Там само. С. 265.

${ }^{36}$ Там само. С. 268.
} 
event of existence, with his dialectics of presence, brightening and concealment, takes place in a word, thus literally in sounding of those words, what name these concepts.

It be possible to say, that all Highdegger's metaphysics passes to the word, in the name as identifications, exactly in this understanding a "language talks". More precisely, in Highdegger's etymologization talks not only language, but existence talks through a language. So the metaphysical reality celled in a word clears up. Dismemberment brings in for him "yes-existence" of perceiving subject. Thus, a word is moment of crossing of Zein and Dazein, existence in general and the existence celled in a subject. A word is poetic here identical to the word a language, and it naturally, in fact a "language is a house of existence". A poetic word belongs to the language, and, thus, through him existence (comes true as, however, and through truth and through art in general. Art in general and poetry in particular differ in only concentrated of this presence.

In the work "Source of artistic creation” about it is talked so: “... an art is strengthening of truth that is built in proof character. It comes true in creation - creation of openness pure. But to lay into creation at the same time means to give motion of existence of creation. And it comes true as a guard. Thus, an art is guard of truth that creates, in creation. Then an art is becoming and realization of truth" ${ }^{\text {" }}$. Thus, in an art and truth, and existence pure hold out in the state of "openness". Naturally, that it is retaining after a contrast and underlines possibilities of their "concealment". In addition, this passing of "concealment" to "openness" becomes a "event" (the "Wonderful belongs to the event of development of truth",38).

The same process of opening-brightening takes place, as we saw, and in a word ("Word - comes forward in the road clearance of existence"). These two processes are laid on each other in a poetry - art of word. Therefore in-process "Source of artistic creation" of M. Highdegger talks that "a poet uses a word, but uses not so as usually people it will be that to dissipate words talk and write, and uses so, that a word first in truth becomes and remains a word"39.

In recent year the line-up of ideas, similar with those expressed by O.O. Potebnia and P.O. Florensky in modern Russian literary criticism. A prime example is the article of M.K. Gey of "Category of artistic value and meta-artistic in literature”.

37 Хайдеггер М. Исток художественного творения // Зарубежная эстетика и теория литературы XIX - XX веков. Москва: Издательство МГУ, 1987. С. 304.

${ }^{38}$ там само. С. 310.

39 там само. С. 287. 
Pulling out conception of meta-artistic, M.K. Gey will nurse from a fundamental taking root words in existence, from bring together a word with that was "at the beginning": "the artistic value of literature can be considered that does a word, trope, character, work, finally, by something more than they are in itself. An artistic value does them mifologema, concept, artistic sense on the different levels of comprehension of the world and artistic work. Word, trope, character, text each of them becomes anymore itself. An artistic value is a synthesis of all elements of maintenance and form in some artistic unit, in work, even in Work as large sense-image" 40 .

Right behind O.O. Potebnia and P.O. Florensky, a researcher asserts fundamental isomorfy of language word and artistic work. This isomorfy is based on their vivid, more precisely, to symbolic nature. (Will pay attention, that a self-symbolic word is in P.O. Florensky "anymore itself”).

Novelty of this conception in claim of fundamental equilibrium offense and to maintenance, when a word becomes to "life sense of that is represented". Therefore, a word is autonomous and self-value: the "Poetic word is self-value in the depth and gap-fillingness. It is an original miracle in the primordialness, and that is why does not tell us something about the world, but becomes the world, and the world tells us or talks to us. A miracle otherwise cannot happen" ${ }^{41}$.

Actually, meta-artistic and is an exposure in the word of some native sense of existence. Impossibility to erect an artistic value that understands so, not only to the art of word but also to the art in general, by a researcher clearly reflected: "Meta-artistic in the logical, concept volumes far will nurse for scopes arts as such. An artistic value is the category transformed on a specific and valued quality of art. Meta-artistic - it already that determines human consciousness. Meta-artistic, unlike an artistic value, does not distinguish an art from anti-art, but tricks into us to his ontological existence sense" ${ }^{\text {,2 }}$.

Problem of this approach - in clear not enough culturological reflected concept of meta-artistic. In the end the already mentioned article of M.K. Gey writes speech "Goes about universal principle of unit or about universal unit: revelation of the world for us and us - to the world. From here is thinking unit and in a word, already in his wild, and by

\footnotetext{
${ }^{40}$ Гей Н.К. Категории художественности и метахудожественности в литературе // Литературоведение как проблема. Москва: Наследие, 2001. С. 285/

${ }^{41}$ Там само. C. 285/

42 там само. С. 228.
} 
means of word, by a word; grasping the sense and pure sense - together, without dividing cracks and defects" ${ }^{43}$.

This thesis is specified at the analysis of Japanese hoku: "It is the world of "clean" existence, equal to the idea, "clean” idea, he as though testifies to absence of dual-ness of man and nature. It is an imperative of achievement of the state of "non-I = I", or "I", that must "be the world”, to be only with him" ${ }^{4}$. Stated by M.K. Gey as an ideal prospect of artistic word the state of consciousness is, essentially, mythological. In fact there is possible equality of "I" and "non-I" exactly in a myth, exactly there "essence of maintenance" meets with maintenance. Exactly there identically, about what to talk, - about "universal principle of unit" or about "universal unit".

Problematical character of this approach is confirmed at the address of scientist to concrete text. Yes, in the deep and rich in content analysis of M.K Gey Pushkin "I loved you" there is such moment: "Heroine is not (it is distinguished by an author - E.S.) in text of work. Work is directed "to her", he creates the situation of returning I to "unknown" in pronominal forms, what called to expose spontaneity and sincerity of lyric creed. Fixes the reverse orientation of internal monologue to her. But it's not there" ${ }^{\text {45 }}$. Really, "favorite woman" as a heroine, in some external displays, details it is not. It is explained by the specific of lyric family. And if not to hear a self-word, if to perceive words "I loved" you, three times repeated, simply as "pronominal forms" that create the "situation of orientation", then it is possible no other presence "her" in a verse not to search. But if it will not be "you", then in the end it will not be and "I": "It not "I", that wishes love to "other", it is an ascent on absolutely other ethic height of experiencing cleared from self" 46 .

How strange - really is not the third given: or "selfish self", or "ethic height of experiencing"? Nevertheless it in different variations recurs "I you". it is the reality celled in a word. And if it so, then "she" exists exactly in this tense of orientation. She exists as "you", as personality, as "sweet one" - identically, by him or "other" - as the valued center. And as "you" it exists in such quality, - there is a lyric subject.

In interpretation of M.K. Gey Pushkin's work develops as successive liberation: at first from "you", then from "I", and then and from sense:

43 Гей Н.К. Категории художественности и метахудожественности в литературе // Литературоведение как проблема. Москва: Наследие, 2001. С. 300.

${ }^{44}$ Там само. С. 294.

45 там само. С. 286.

46 там само. С. 286. 
"...loved" - becomes original expression of the passion purged from everything passionate" 47 . And there are only a "absolute word" and "reality of ethic reality"48. Very beautifully and very coldly. It goes out that the absolute in instantaneous is not present, it goes out that eternal maybe only as a release from temporal: so, looks out in the real embodiment "vertical modus of meta-artistic"49.

But, obviously, in a normal artistic value somehow differently. In all multiplicity instantaneous and only through her there is absolute and eternal. Every moment of this multiplicity for absolute is needed - and the absolute links exactly, revolves one to one "I" and "you", "absolute passion" and "instantaneous passion".

Asserts ontological status of poetic word and such original phenomenon of modern science, as "religious philology". In brackets will say, that analogy with religious philosophy in this case really not fully appropriate. The point is that Russian religious philosophy on verge of XIX - XX of centuries was formed not only in realization of crisis of philosophical knowledge but also crises of religious consciousness. Religious philosophy showed "indivisibility and impossibility of unity" religions and philosophy. And, obviously, fruitful collaboration of two areas of culture and it is possible only at finding out of their mutual necessity to one another.

Problematical character of "religious philology" is not only in that religion becomes a panacea for a study of literature science and for an art (the article of T.O. Kasatkina is in this plan very symptomatic). And even not in the strange fracture of logic, that forces to search the specific of any phenomena (in this case - poetic word) not in that really only him peculiar to, but in that peculiar and to other phenomena.

Mythologism, that showed up in the work of M.K. Gey quoted higher, increases and associated strange character with a Christian religiousness. Here description of world view, organic for a "word, that creates reality" that is given by T.O. Kasatkina: "In the world view of old style she (man) naively inlaid the soul in a thing, she could examine the person as the world face, to see itself similarity of God for the grandeur of that it was not very difficult to pay some punishments of hell”50.

\footnotetext{
47 Гей Н.К. Категории художественности и метахудожественности в литературе // Литературоведение как проблема. Москва: Наследие, 2001.С. 287.

${ }^{48}$ Там само. С. 287.

${ }^{49}$ Там само. С. 291.

50 Касаткина Т.А. Слово, творящее реальность, и категория художественности // Литературоведение как проблема. Москва: Наследие, 2001. С. 321.
} 
And further in her work, without regard to active claim of Christianity as an ideal prospect of a study of literature science, the basic categories of this science are characterized, coming from a myth. Writer T.A. Kasatkina names a "magician" "natural magic"52. Speech goes about mythological substrate of religion, that, certainly, is everywhere, in any industry of human culture. Is there he, certainly, and in an artistic word, only here question: or it costs to erect an artistic value to him and, on the other hand, to search this mythological substrate in an artistic word, but not in some other phenomena? In any event, as us it seems to, this phenomenon in literary criticism far more faithful would be to name "mythological philology".

In a myth subject of yet not separated, that is why a problem of subject is another problem of "religious philology". There is some strange not that slight a creative subject, but, in any event, leading-out of him outside an artistic word. T.O. Kasatkina generalizes this tendency: “...the real style gives birth as penetration of author depth first object, as understanding of internal principle of thing an author, as expression of the world, but not itself" 53 . "I" and "world" is not simply divorcees here, but opposite. A word, thus, appears the mestome of quite not "meeting" (O.F. Losev), and opposition.

It is confined connection with a subject, a word loses the contexts, becoming not only by something separate but also ready. Such word needs actualization only, but to not work. Very clearly it is visible in the finale of the article of T.O. Kasatkina: "Main principle of the described method is capturing of existence of word in primary reality - speaking more straight and more frank, уловлення of that reality that is initially contained by a word"54. It is twice repeated "primary" it is possible to understand, coming from the context of the article, and as direct sense of word, and as an ascent to the that word that "was at the beginning", although last obviously outside province of literary critic. However researchers absolutely clear: reality of word of not given, but set, she unchanging.

Very characteristic moment: there is an only case in the article, when T.O. Kasatkina analyses the real artistic word, but not points him for illustration of own theoretical positions. It is her interpretation of phrase of «Ишь, нарезался!» in "Crime and punishment" of F.M. Dostoevsky. And

51 Касаткина Т.А. Слово, творящее реальность, и категория художественности // Литературоведение как проблема. Москва: Наследие, 2001. С. 332.

${ }^{52}$ Там само. С. 329.

53 Там само. С. 319.

54 Там само. С. 338. 
a researcher does not notice here, that an artistic effect is created by quite not in itself direct sense of word. He is formed by the field of tension between this direct value and portable - that in that it it is used in this context. Clear, that it the field of tension is created someone, but not exists indigenously. Thus a researcher does not take into account exactly dynamic and in this becoming deeply individual character of artistic reality.

Conception of T.O. Kasatkina looks yet more contradictory, when speech calls about correlation of this reality with a word. From one side, this reality is inseparable from a word, she - in it, ready and unchanging: "Essence of our approach consists in a look to the word as on the continue substance of artistic text. A similar look is possible in case that it is envisaged that a word contains certain reality not dependency upon will of participants of communicative act, reality that they can only notice or not to notice, to realize or not realize..." ${ }^{55}$. But, on the other hand, it appears then, that this reality is quite not in a word, and after a word. There is the impression, that a researcher does not feel that such change of position of reality changes business substantially. Literally on a next page then the higher brought claim over of T.O. Kasatkina writes: "Then artistic value that is not that other, as reality that gets up after a word (underline by me - E.S.) disappears from his text" ${ }^{\prime 56}$.

Actually, here herein and main problem: when reality is out of word, it becomes a "empty form" (R. Bart). Then reality that disappeared from a word but illusive in this word contained a researcher, appears, essentially, by reality cleanly human, ethic. It is fully possible to agree with claim of B. Nepomniashy: to "Listen all word, but not only ego harmony" 57 . But on condition that "all word" does not exist out of harmony. But farther, concerning a polemic from C. Bocharov, B. Nepomniashy writes: worries "me, that Pushkin experiences and about what talks, and C. Bocharov - as Pushkin sings"58. But "that Pushkin experiences and about what talks", exists only in that, "as he sings", if speech really about A. Pushkin.

Really, there is a necessity to "listen all word" - but with an accent exactly on to "listen", thus process, but not on a result, on flowing of word, on co-operating with other. If not to do it, if to look at a word as on the prepared essence after that there is reality, then it is then possible it as easy as anything to pass by and artistic specific of work, and his author,

\footnotetext{
55 Касаткина Т.А. Слово, творящее реальность, и категория художественности // Литературоведение как проблема. Москва: Наследие, 2001. С. 332.

${ }^{56}$ Там само. С. 333.

57 Непомнящий В. О горизонтах познания и глубинах сочувствия // Литературоведение как проблема. Москва: Наследие, 2001. С. 531.

${ }^{58}$ Там само. С. 541.
} 
replacing it (that it is convincingly shown in the article of S.G. Bocharov "About religious philology").

It costs to underline that, at all likeness of initial parcel - claim of ontological status of poetic word - between conception of meta-artistic of M.K. Gey and "religious philology" is a deep difference. A poetic word is in M.K. Gay - work of the special world that shows sense of existence, and in "religious philology" is realization of the prepared maintenance. M.K. Gey asserts the value of word, and "religious philology" - its service and illustration role.

\section{CONCLUSION}

Thus, we found out, that in all the varieties of approaches to an artistic word as to the sign it is still possible to see some common traces. A word contains a reality, it is identical to the object, and thus appears a monad in Leibnits's sense. An image nature of word is generalized here, as well as the fact of the word being "more than itself" (as per P.O. Florensky, O.F. Losev, M. Highdegger and, right after them, in H.K. Gey) is being understood as word's over-context, closed existence. The idea of equality constitutes more or less admitted mythologism. It is most admitted in the works of O.F. Losev, which allows him to create a complex and dynamic conception of word, that partly overcomes the mentioned above monadity ("the name of an object is an arena of meeting of who perceives and the perceived"). The fundamental isomorfiness of a language word and of artistic word is established on the basis of their image nature and relation to what is wider than any of them (For M. Highdegger a language is "the house of existence", a poetic word belongs to the language and, as a result, to existence; for M.K. Gey the "meta-artistic" is "what determines human consciousness"). The issue of creative subject is reviewed, which appears to be only a mediator between reality that is contained in a word, and the reader (M. Highdegger: “... an artist becomes something self-less compared to the creation").

The basic features of study of word as separate aesthetic reality slightly differ. A word is understood as the special reality the embodies individual creative intentions, and as a result it becomes a new name for a new object (as writes G.O. Vinokur: "language... is all centered around the theme and idea of artistic intention"). The special reality of word has an organized character that is determined by co-operation of linguistic and individual-authorial senses of a word (a category of internal form of G.O. Vinokur, co-operation of primary and additional senses, primary 
and additional sounding for D.K. Rensom). The category of creative subject is accented. It's function is creation of "new moduse of language reality" (G.O. Vinokur), transformation of outgoing value and sound (D.K. Rensom).

\section{SUMMARY}

The work is dedicated to the problem of artistic word - one of the principal and most important problems of the modern literary theory. The author describes, systematizes and analyses the concept of artistic word as a sign in the modern literary theory, based upon the works of O.F. Losev, G.O. Vikokur, D.K. Rensom, M. Highdegger, M.K. Gey and others. It is shown that in the works of O.F. Losev the word is a mediator between the subject and the esistence, between life and existence; a mediator which holds the treats of all phenomena it mediates. Upon analysing a set of works of Highdegger we define, that a word for this philosopher was an intersection point of Zein and Dazein, of e existence in general and existence concentrated in a subject. A poetic word here is identical to a linguistic word, which is natural as "language is a house existence". As a result of comparison of works "Category of artistic and meta-artistic in literature" of M.K. Gay and "Word that creates reality, and category of artistic value" of T. Kasatkina clearly show that there is a deep difference between the conception of meta-artistic of M.K. Gey and "religious philology". A poetic word for M.K. Gay is a creation of a special world that demonstrates existential traits, whereas for "religious philology" it is a realization of the ready-made sense. M.K. Gey states the proper value of a word, as opposed to "religious philology" which states it's service-illustrative role.

\section{REFERENCES}

1. Потебня А.А. Эстетика и поэтика. Москва: Искусство, 1976. $614 \mathrm{c}$.

2. Флоренский П.А. Имеславие как философская предпосылка // Флоренский П.А. У водоразделов мысли. Москва: Правда, 1990. Т. 2. С. 281-338.

3. Лосев А.Ф. Философия имени. Москва: Издательство МГУ, 1990. 269c.

4. Винокур Г.О. О языке художественной литературы. Москва: Высшая школа, 1991. 448 с. 
5. Рэнсом Д.К. «Новая критика» // Зарубежная эстетика и теория литературы XIX - XX веков. Москва: Издательство МГУ, 1987. C. 177-194.

6. Хайдеггер М. Исток художественного творения // Зарубежная эстетика и теория литературы XIX - XX веков. Москва: Издательство МГУ, 1987. С. 264-313.

7. Хайдеггер М. Время и бытие. Москва: Республика, 1993. 447 с.

8. Гей Н.К. Категории художественности и метахудожественности в литературе // Литературоведение как проблема. Москва: Наследие, 2001. С. 280-301.

9. Касаткина Т.А. Слово, творящее реальность, и категория художественности // Литературоведение как проблема. Москва: Наследие, 2001. С. 302-346.

10. Непомнящий B. О горизонтах познания и глубинах сочувствия // Литературоведение как проблема. Москва: Наследие, 2001. C. 524-571.

\section{Information about the author:} Sventsitskaya E. M., Doctor of filology, Professor, Department of Slavic Philology and Journalism, Academic and Scientific Institute of Philology and Journalism, V. I. Vernadsky Taurida National University 33, John McCain str., Kyiv, 01042, Ukraine 